\title{
Interleukin-10 receptor deficiency in a Polish paediatric patient with early onset inflammatory bowel disease
}

\author{
Niedobór receptora dla interleukiny 10 u dziecka z wczesną manifestacją \\ nieswoistego zapalenia jelit
}

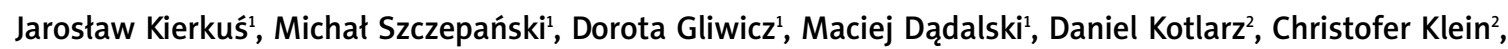
Józef Ryżko' ${ }^{1}$, Piotr Socha ${ }^{1}$
\end{abstract}

1Department of Gastroenterology, Hepatology and Feeding Disorders, The Children's Memorial Health Institute, Warsaw, Poland 2University Children's Hospital Munich, Dr. von Hauner Children's Hospital, Ludwig Maximilian University Munich, Germany

Key words: inflammatory bowel diseases, children, interleukin-10.

Stowa kluczowe: nieswoiste zapalenia jelit, dzieci, interleukina 10.

\begin{abstract}
Address for correspondence: Jaroslaw Kierkuś MD, PhD, Department of Gastroenterology, Hepatology and Feeding Disorders, The Children's Memorial Health Institute, Al. Dzieci Polskich 20, 04-730 Warsaw, Poland, phone: +48 228157384, fax: +48 228157382 , e-mail: j.kierkus@czd.pl
\end{abstract}

\begin{abstract}
Inflammatory bowel disease (IBD), which includes Crohn's disease (CD) and ulcerative colitis (UC), is a chronic condition characterized by abdominal pain, diarrhoea, bleeding, and malabsorption. The disease is common in young people (children and young adults) yet it is rather rare in children younger than 2 years. A distinct phenotype of early onset IBD (EO-IBD) in infants and small children with severe intractable enterocolitis and greater tendency to develop colonic disease has been described. Recent work has demonstrated that EO-IBD with manifestation in the first months of life can be monogenic, resulting from mutations in interleukin-10 (IL-10) or its receptor and leading to a loss of IL-10 function. Allogeneic haematopoietic stem cell transplantation (HSCT) can be a successful treatment for those patients. We present here a case of a female IL-10R-deficient patient with severe EO-IBD who underwent HSCT.
\end{abstract}

\section{Introduction}

Inflammatory bowel disease (IBD), which includes Crohn's disease (CD) and ulcerative colitis (UC), is a chronic condition of the colon and small intestine [1]. Both types of IBD may present with any of the following symptoms: abdominal pain, vomiting, diarrhoea, rectal

\section{Streszczenie}

Nieswoiste zapalenia jelit (inflammatory bowel disease - IBD), które obejmują chorobę Leśniowskiego-Crohna i wrzodziejące zapalenie jelit, stanowią grupę przewlekłych chorób układu pokarmowego. Do charakterystycznych objawów należą: ból brzucha, biegunka, krwawienie z dolnego odcinka przewodu pokarmowego oraz niedożywienie. Choroba często pojawia się w młodym wieku (dzieci i młodzi dorośli), jednak stosunkowo rzadko u dzieci młodszych niż 2 lata. U pacjentów z wczesną manifestacją IBD (EO-IBD) choroba często lokalizuje się w jelicie grubym, jej przebieg jest ciężki i szybko rozwija się zapalenie całego jelita grubego. Najnowsze doniesienia wskazują na związek EO-IBD zdiagnozowanej w pierwszych miesiącach życia z defektem monogenicznym i mutacjami interleukiny 10 (IL-10) i/lub jej receptora, co powoduje utratę funkcji IL-10. Przeszczep allogenicznych komórek szpiku (haematopoietic stem cell transplantation - HSCT) stanowi jedyne skuteczne leczenie dla tych pacjentów. Autorzy przedstawiają przypadek pacjentki z deficytem IL-10R oraz ciężkim przebiegiem EO-IBD, która przeszła HSCT.

bleeding, severe internal cramps/muscle spasms in the region of the pelvis, weight loss and various associated complaints or diseases such as arthritis, pyoderma gangrenosum and primary sclerosing cholangitis. The diagnosis is based mainly on colonoscopy with biopsy of pathological lesions [1, 2]. The disease is common in children and adolescence, yet it is rather infrequent in chil- 
dren younger than 2 years old [2]. Therefore IBD developing during the first years of life (under the age of 5) is classified as an early-onset IBD (EO-IBD) and it is considered to be a specific entity with a distinct phenotype [3]. The disease manifestations are primarily colonic, with severe perianal disease, and severe extra-gastrointestinal manifestations [4, 5]. The EO-IBD usually has very severe manifestations and an uncertain prognosis with life-threatening symptoms, and needs an aggressive therapeutic approach [5]. Recent studies have demonstrated that EO-IBD with onset during the first years of life may stem from inherited monogenetic defects in signalling pathways that control intestinal homeostasis, leading to defective anti-inflammatory responses [6]. The available data point to the complexity of EO-IBD, representing a group of distinct diseases with several pathogenetic abnormalities, as recently suggested by impaired IL-10 signalling [7-9]. Allogeneic stem cell transplantation may result in disease remission in those patients [10].

We report a case of a female patient with severe very early onset CD and IL-10 receptor deficiency who underwent allogeneic haematopoietic stem cell transplantation (HSCT).

\section{Case report}

A 6.5-year-old girl, a second child of healthy parents, born in the $40^{\text {th }}$ gestational week, who scored 10 points on the Apgar scale test, was diagnosed with CD at the age of 5 months. The first symptoms of the disease appeared when the girl was only 4 weeks old. She presented with chronic diarrhoea, prolapse of the anus and perirectal abscess. At that time, she was exclusively breastfed, the mother being on a hypoallergenic diet due to the infant's suspected food allergy. At the age of 9 weeks, due to persistent and aggravating clinical symptoms, the patient was hospitalized and underwent diagnostics. Endoscopic examination showed severe inflammatory lesions, ulcerations, erosions and aphthous lesions in the colon and rectum. Figure 1 presents the endoscopic features of the disease. Imaging tools confirmed the presence of a perianal abscess. After differential diagnosis and exclusion of an immunological deficiency (family history of immunological diseases was negative) the patient was diagnosed with CD. Results of immunological testing are presented in Table I. Pharmacotherapy with steroids, azathioprine (AZA) and sulphasalazine together with total parenteral nutrition (TPN) for 3 months was administered with a partial clinical response, but no healing of the perianal abscess was observed. At the age of 3.5 months, due to disease relapse with recurrence of diarrhoea, persistent perirectal abscess, steroid dependence, and iatrogenic Cushing syndrome, the patient was admitted to hospital. In view of the refractory course the decision of ileostomy was made (following surgical consultation). The operation was performed with a positive effect. Since that time our patient has been hospitalized many times, mostly due to episodes of exacerbations of $C D$ and frequent infectious complications such as life-threatening methicillin-resistant Staphylococcus aureus (MRSE) sepsis with hypoten-
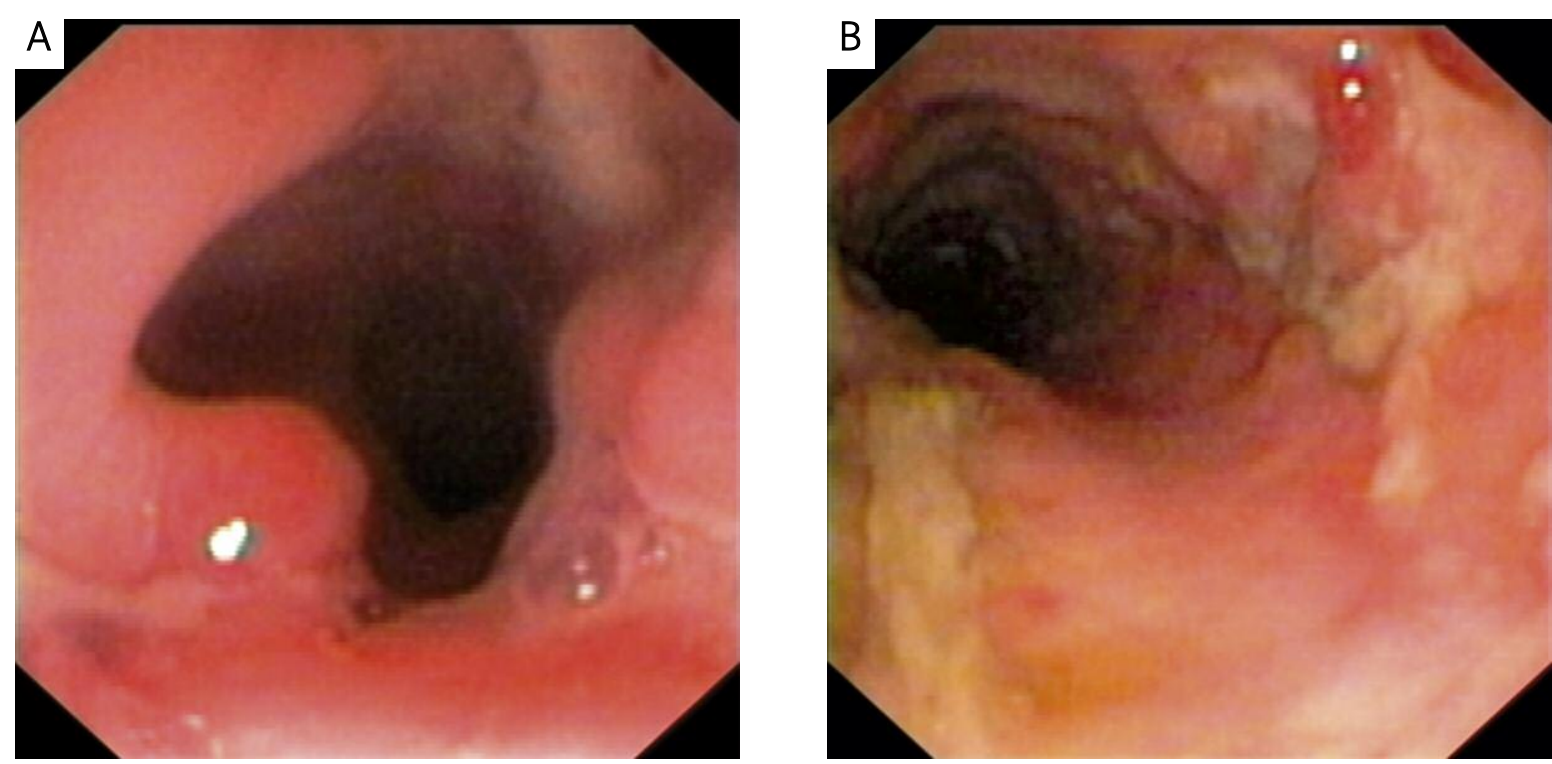

Fig. 1. The endoscopic features of disease lesions: A - stiff and shortened bowel, B - inflammatory lesions, ulcerations, erosions and apthous lesions in the colon and rectum

Ryc. 1. Endoskopowe zmiany chorobowe: $A$ - sztywne i skrócone jelito, B - zmiany zapalne, owrzodzenia, nadżerki i afty $w$ jelicie grubym i odbytnicy 
Table I. Results of immunological exams of our patient: immunoglobulines profile and lymphocyte phenotype

Tabela I. Wyniki badań immunologicznych u opisywanej pacjentki: profil immunoglobulin i fenotyp limfocytów

\begin{tabular}{cccccc} 
Date & IgG & IgM & IgA & IgE & \\
\cline { 1 - 4 } $2011-05$ & 456 & 103 & 59 & x & \\
\hline Date & No lymphocytes & CD4 no absolu & CD8 no absolu & CD4CD25 h \% & NK \\
\hline $2011-05$ & 1335 & 715 & 475 & 10 & 41
\end{tabular}

sive shock and acute renal failure. At the age of 1 year, a recurrence of the intestinal disease was observed. The patient presented with lack of appetite, nausea, vomiting and sporadic episodes of coffee-ground vomiting. Endoscopic examination showed inflammatory lesions in the stomach, reminiscent of endoscopic features of $C D$, and inflammation in the large intestine. After completing all formalities, a skin test for tuberculosis and X-ray examination of the thorax were performed and biological therapy with infliximab was administered upon approval of the Institutional Review Board and caregivers' consent. Our patient received 2 doses of the drug with a positive effect. After the second dose, however, an episode of hypothermia and hypotension was recorded and the patient's state deteriorated again (as before the administration of the drug). The therapy was discontinued. At the age of 4 years, she was hospitalized due to intestinal obstruction secondary to adynamic ileus. In view of recurrent relapses of the disease the patient was qualified for biological therapy with adalimumab. She received 3 doses of the drug (induction therapy). Even though the patient responded to the medication and her clinical state significantly improved, she did not enter full remission, since the perianal abscess and rectal condyloma reappeared, and significant growth retardation $\left(<3^{\text {rd }}\right.$ percentile) was observed. At 6 years of age, our patient underwent molecular investigation which revealed IL-10R deficiency a monogenetic defect causing EO-IBD. The HSCT was performed which induced a clinical with a follow-up time of 1 year.

\section{Discussion}

Inflammatory bowel disease is uncommon in children younger than 2 years. A distinct phenotype of EO-IBD is described, with a high familial aggregation in UC and greater tendency to develop colonic disease [4]. In different studies, young age at diagnosis was described as a predictive parameter of a complicated disease course [11], and of an increased risk for future immunosuppressive therapy [12], surgery, and recurrence rates [13].

Our patient showed the first symptoms at the age of 4 weeks and was diagnosed with CD at the age of
5 months. Disease presentation in our patient was predominantly colonic (colon and rectum), although some inflammatory lesions in the stomach could also correspond to the endoscopic features of $C D$ in the large intestine, which is a typical localization for EO-IBD. The patient had no reported family members with IBD; however, first-degree family history is more typical for early onset UC than CD.

The clinical course of $C D$ is highly variable and ranges from a single episode to a potentially life-threatening continuous disease [14]. In our case the disease appeared to be very severe with a high rate of recurrence: the patient underwent total parenteral nutrition (TPN), required ileostomy and an aggressive, multidrug, immunosuppressive approach (AZA, infliximab, adalimumab). However, the characteristics of EO-IBD are not determined yet, as this highly diverse paediatric cohort revealed demographically related variation in the distribution of disease phenotype. The analysis of IBD presentation in the population-based Veszprem Province database revealed that early disease course in this paediatric cohort was milder compared to data reported in the literature [15].

The EO-IBD with manifestation in the first months of life and mimicking Crohn's disease can be caused by a particular genetic defect. Recent works have demonstrated that mutations in the $I L 10$ receptor alpha and beta chain (ILIORA, ILIORB), as well as the IL10 gene, both leading to a loss of IL-10 function, are likely to be the possible aetiology [11]. Most of the patients with defective IL-10-mediated signalling described in the literature were born to consanguineous parents, presenting with symptoms in the first months of life in the form of severe colitis and perianal disease. The small bowel usually was not involved and autoimmune symptoms were generally not observed. No significant genotypephenotype correlation was found among patients with different IL-10-related gene defects. Complex multimodal therapy approaches failed to control the clinical course, with only the biological treatment giving a transient response. After the diagnosis of a defective IL-10 axis, successful HSCT was performed in 5 patients (REF), which reflects the importance of functional IL-10-mediated signalling for intestinal homeostasis. 
In view of these data, presented by Glocker et al., we decided to initiate genetic diagnostics in our EO-IBD patient. DNA Sanger sequencing on genomic DNA revealed a mutation in the IL10RB gene (c.G611A; p.Trp204X). Functional assay on peripheral blood mononuclear cells confirmed IL-10R deficiency, and thus the girl was qualified for haematopoietic stem cell transplantation.

In conclusion, it is of great importance to take IBD into consideration at differential diagnosis in infants presenting with vomiting, diarrhoea, rectal bleeding or malabsorption, and in poor general state. The EO-IBD is described as having a distinct phenotype with a severe prognosis; however, its clinical course may be genetically determined and demographically variable, which suggests that treatment and outcome may vary. It is crucial to consider that impaired IL-10-mediated signalling may characterize EO-IBD patients and for those children haematopoietic stem cell transplantation seems to be a successful treatment. Prompt diagnosis might prevent unnecessary advanced pharmacological and surgical treatments [16]

\section{References}

1. Baumgart DC, Carding SR. Inflammatory bowel disease: cause and immunobiology. Lancet 2007; 369: 1627-40.

2. Heyman MB, Kirschner BS, Gold BD, et al. Children with early-onset inflammatory bowel disease (IBD): analysis of a pediatric IBD consortium registry. J Pediatr 2005; 146: 35-40.

3. Paul T, Birnbaum A, Pal DK, et al. Distinct phenotype of early childhood inflammatory bowel disease. J Clin Gastroenterol 2006; 40: 583-6.

4. Cannioto Z, Berti I, Martelossi S, et al. IBD and IBD mimicking enterocolitis in children younger than 2 years of age. Eur J Pediatr 2009; 168: 149-55.

5. Walker-Smith JA, Lebenthal E, Branski D. Pediatric and inflammatory bowel disease: perspective and consequences. Pediatr Adolesc Med 2009; 14; 67-75.

6. Begue B, Verdier J, Rieux-Laucat F, et al. Defective IL10 signaling defining a subgroup of patients with inflammatory bowel disease. Am J Gastroenterol 2011; 106: 1544-55.

7. Henderson P, van Limbergen JE, Wilson DC, et al. Genetics of childhood-onset inflammatory bowel disease. Inflamm Bowel Dis 2011; 17: 346-61.

8. Imielinski M, Baldassano RN, Griffiths A, et al. Common variants at five new loci associated with early-onset inflammatory bowel disease. Nature Genetics 2009; 41: 1335-40.

9. Fiedler T, Büning C, Reuter W, et al. Possible role of MDR1 twolocus genotypes for young-age onset ulcerative colitis but not Crohn's disease. Eur J Clin Pharmacol 2007; 63: 917-25.

10. Glocker EO, Kotlarz D, Boztug K, et al. Inflammatory bowel disease and mutations affecting the interleukin-10 receptor. N Engl J Med 2009; 361: 2033-45.

11. Romberg-Camps MJ, Dagnelie PC, Kester AD, et al. Influence of phenotype at diagnosis and of other potential prognostic factors on the course of inflammatory bowel disease. Am J Gastroenterol 2009; 104: 371-83.
12. Wenger S, Nikolaus S, Howaldt S, et al. Predictors for subsequent need for immunosuppressive therapy in early Crohn's disease. J Crohn's Colitis 2012; 6: 21-8.

13. Gupta N, Cohen SA, Bostrom AG, et al. Risk factors for initial surgery in pediatric patients with Crohn's disease. Gastroenterology 2006; 130: 1069-77.

14. Henriksen M, Jahnsen J, Lygren I, et al. Clinical course in Crohn's disease: results of a five-year population-based follow-up study (the IBSEN study). Scand J Gastroenterol 2007; 42: 602-10.

15. Lakatos L, Kiss LS, David G, et al. Incidence, disease phenotype at diagnosis, and early disease course in inflammatory bowel diseases in Western Hungary, 2002-2006. Inflamm Bowel Dis 2011; 17: 2558-65.

16. Kotlarz D, Beier R, Murugan D, et al. Loss of interleukin-10 signaling and infantile inflammatory bowel disease: implications for diagnosis and therapy. Gastroenterology 2012; 143: 347-55. 